\title{
SALICYLIC ACID AMELIORATES THE ADVERSE EFFECT OF SALT STRESS ON STRAWBERRY
}

\author{
Huseyin Karlidag ${ }^{1}$; Ertan Yildirim ${ }^{1 *} ;$ Metin Turan $^{2}$ \\ ${ }_{2}^{1}$ Atatürk University Ispir Hamza Polat Vocational Training School 25900, Ispir, Erzurum - Turkey \\ ${ }^{2}$ Atatürk University Faculty of Agriculture, Department of Soil Science Erzurum-Turkey \\ *Corresponding author $<$ ertanyil@atauni.edu.tr $>$
}

\begin{abstract}
Strawberry is considered as a salinity sensitive species and is adversely affected in response to the salt stress in terms of growth and yield. Pot experiments were conducted to determine the effect of exogenous salicylic acid (SA) application on physiology, growth, chlorophyll and mineral content of strawberry grown under salt stress and greenhouse conditions. Strawberry plants were treated with SA at different concentrations $(0.0,0.25,0.50$ and $1.00 \mathrm{mM})$. Salinity treatments were established by adding 0 and $35 \mathrm{mM}$ of $\mathrm{NaCl}$ to a base complete nutrient solution. Salt stress negatively affected the growth, chlorophyll content and mineral uptake of strawberry plants. However, plants treated with SA often had greater shoot fresh weight, shoot dry weight, root fresh weight and root dry weight as well as higher chlorophyll content under salt stress. The greatest values were obtained with $1.00 \mathrm{mM}$ SA treatment in both saline and non-saline conditions. Leaf water relative content (LWRC) was reduced in response to salt stress while electrolyte leakage was raised. SA treatments induced increases in LWRC and decreases in electrolyte leakage compared to the control under salt stress. With respect to the nutrient content, SA treatments increased almost contents of all nutrients in leaves and roots of strawberry plants under salt stress. The greatest values were often obtained by the $1.00 \mathrm{mM}$ SA treatment. These findings suggest that the SA treatments can ameliorate the negative effect of salinity on the growth of strawberries.
\end{abstract}

Key words: salinity, growth, mineral content

\section{MELHORA DO EFEITO DE ESTRESSE SALINO EM MORANGO PORADIÇÃO DE ÁCIDOSALICÍLICO}

\begin{abstract}
RESUMO: O morango é considerado uma espécie sensível à salinidade e é negativamente afetado por estresse salino, em termos de crescimento e produção. Por meio de experimentos em vaso foi determinado o efeito de ácido salicílico exógeno (SA) na físiologia, crescimento, conteúdos de clorofila e de minerais, em morangueiros cultivados em estufa sob estresse salino. As concentrações de SA foram $0.0,0.25,0.50$ e $1.00 \mathrm{mM}$. O estresse salino foi verificado pela adição de 0 e $35 \mathrm{mM}$ de $\mathrm{NaCl}$ à uma solução nutritiva completa. $\mathrm{O}$ estresse salino afetou negativamente o crescimento, o conteúdo de clorofila e a absorção dos nutrientes minerais. Entretanto, plantas tratadas com SA muitas vezes apresentam maiores pesos frescos e secos, além de maior concentração de clorofila, sob condições de estresse salino. O conteúdo relativo de água das folhas (LWRC) foi reduzido em resposta ao estresse salino, enquanto o extravasamento de eletrólitos aumentou. Os tratamentos com SA induziram a aumentos em LWRC e diminuições no extravassamento de eletrólitos, em comparação com os controles sob estresse salino. Com respeito aos conteúdos de nutrientes, houve aumento para quase todos os nutrientes com adição de SA nas folhas e raízes sob estresse salino. Os maiores valores forma geralmente obtidos para $1.00 \mathrm{mM}$ SA. Estes resultados sugerem que os tratamentos com SA podem atenuar os efeitos negativos da salinidade no crescimento do morangueiro.

Palavras-chave: salinidade, crescimento, conteúdo mineral
\end{abstract}

\section{INTRODUCTION}

Salinity is one of the major environmental factors limiting plant growth and productivity. It is estimated that about one-third of world's cultivated land is affected by salinity (Kaya et al., 2002). Excess salt in the soil may adversely affect plant growth either through osmotic inhibition of water uptake by roots or specific ion effects. Specific ion effects may cause direct toxicity or, alternatively, the insolubility or competitive absorption of ions may affect plant nutritional balances (Greenway \& Munns, 1980). Salt stress has toxic effects on plants and lead to metabolic changes, like loss of chloroplast activity, decreased photosyn- 
thetic rate and increased photorespiration rate which then leads to an increased reactive oxygen species (ROS) production (Parida \& Das, 2005).

Strawberry is considered as a $\mathrm{NaCl}$ salinity sensitive species (Saied et al., 2005) and it has been shown to reduce leaf number, leaf area, shoot dry weight and number of crowns and low yield (Pirlak \& Esitken, 2004).

Strategies for alleviation of salt stress involve developing salt-resistant cultivars, leaching excess soluble salts from upper to lower soil layers, flushing soils that contain salt crusts at the surface, reducing salt by harvesting salt-accumulating aerial plant parts in areas with negligible irrigation water or rainfall for leaching, and amelioration of saline soils under cropping and leaching (Qadir et al., 2000). Breeding for tolerance to salinity in crops has usually been limited by a lack of reliable traits for selection. Multiple genes seem to act in concert to increase salinity tolerance, and certain proteins involved in salinity stress protection have also been recognized (MurilloAmador et al., 2006). Therefore, the development of methods and strategies to ameliorate deleterious effects of salt stress on plants has received considerable attention. Enhancing stress tolerance in plants has major implications in agriculture and horticulture (Senaratna et al., 2000). SA has been shown as an important signal molecule for modulating plant responses to environmental stress (Breusegem et al., 2001). The ameliorative effects of SA have been well documented in inducing salt tolerance in many crops (Aldesuquy et al., 1998; El-Tayeb, 2005; Gunes et al., 2005; Stevens et al., 2006).

During the last decade strawberry production has spread in almost all parts of Turkey. Total annual production now amounts to 120,000 tones. Almost all of this production comes from small family farms of 0.05-0.5 hectares. Strawberries are unique with highly desirable taste, flavor, and excellent dietary sources of ascorbic acid, potassium, fibre and other secondary metabolites and also simple sugar sources of energy (Perez et al., 1997; Wang \& Galletta, 2002).

The effect of SA on growth and nutrient uptake on strawberry under salt stress conditions has yet not been well studied. Therefore, this experiment focuses on the effect of different concentrations of SA on plant growth, chlorophyll and mineral content of strawberries under salt stress.

\section{MATERIALAND METHODS}

\section{Growth conditions and plant materials}

The study was conducted in Erzurum (40 31'
N; 40 54' E) Turkey, in 2007, under greenhouse conditions. Strawberry (Fragaria x ananassa Duch.) 'Fern' plants were maintained under natural light conditions, approximate day/night temperatures of $24 / 19^{\circ} \mathrm{C}$ and $75 \%$ relative humidity during the span of the experiment.

Cold-stored bare rooted strawberry seedlings with one well-developed crown of diameter 8-10 mm were planted in celled-trays containing peat $(\mathrm{pH}: 5.5$, EC:250 mmho $\mathrm{cm}^{-1}, \mathrm{~N}: 300 \mathrm{mg} \mathrm{L}^{-1}, \mathrm{P}_{2} \mathrm{O}_{5}: 300 \mathrm{mg} \mathrm{L}^{-1}$, $\mathrm{K}_{2} \mathrm{O}: 400 \mathrm{mg} \mathrm{L}^{-1}$, organic matter: $20 \mathrm{~g} \mathrm{~kg}^{-1}$ ).

Twenty days after planting (DAP) they were transplanted to pots $(20$ and $17 \mathrm{~cm}$ top and bottom diameter respectively, and $20-\mathrm{cm}$ height, with holes in the bottom) filled with mixture of peat:vermiculite (1:1, $\mathrm{v}: \mathrm{v})$. Pots were placed randomically on the benches in the greenhouse. There were 4 replicates per treatment and 10 plants per replicates.

\section{SA treatments}

Salicylic acid (SA; 2-hydroxybenzoic acid) was initially dissolved in $100 \mu \mathrm{L}$ dimethyl sulfoxide and concentrations of $0.25,0.50$ and $1.00 \mathrm{mM}(\mathrm{pH} 6.0-6.5)$ were made up with distilled water containing $0.02 \%$ Tween 20 (Polyoxyethylenesorbitan monolaurate, Sigma Chemicals, UK) (Khan et al., 2003). At 15 DAP plants were treated with distilled water or one of the solutions of $0.25,0.50$ and $1.00 \mathrm{mM} \mathrm{SA}$.

\section{Salt $(\mathrm{NaCl})$ treatments}

Salinity treatments were established at transplant time by adding 0 and $35 \mathrm{mM}$ of $\mathrm{NaCl}$ to a base complete nutrient solution of (\%): $\mathrm{N}, 17 ; \mathrm{P}_{2} \mathrm{O}_{5}, 9 ; \mathrm{K}_{2} \mathrm{O}$, $31 ; \mathrm{Mg}, 2 ; \mathrm{SO}_{4}, 4 ; \mathrm{Na}, 0.001 ; \mathrm{Fe}, 0.02 ; \mathrm{Zn}, 0.002$; $\mathrm{Cu}, 0.002 ; \mathrm{B}, 0.01 ; \mathrm{Mn}, 0.01 ; \mathrm{Mo}, 0.001$. The electrical conductivities of these solutions after adding 0 and $35 \mathrm{mM}$ of $\mathrm{NaCl}$ were determined with a conductivity meter, Model 470 (Jenway Limited). Electrical conductivities (EC) of these solutions were $1.62 \mathrm{dS}$ $\mathrm{m}^{-1}$ for $0 \mathrm{mM} \mathrm{NaCl}$ and $4.41 \mathrm{dS} \mathrm{m}^{-1}$ for $35 \mathrm{mM} \mathrm{NaCl}$. All pots were irrigated to field capacity with 0 or 35 $\mathrm{mM}$ saline solutions to maintain the level of salinity after transplanting.

\section{Chlorophyll measurements}

A portable chlorophyll meter (SPAD-502, Konica Minolta Sensing, Inc., Japan) was used to measure leaf greenness of the plants. SPAD-502 chlorophyll meter can estimate total chlorophyll amounts in leaves of a variety of species with a high degree of accuracy, which is a non-destructive method (Neufeld et al., 2006). For each plant, measurements were taken at four locations on each leaf, two on each side of the midrib on all fully expanded leaves and then averaged (Khan et al., 2003). 


\section{Measurement of electrolyte leakage (membrane permeability)}

For measurement of electrolyte leakage, 10 leaf discs (10 $\mathrm{mm}$ in diameter) from the young fully expanded leaves from two plants per replicate were placed in $50 \mathrm{~mL}$ glass vials, rinsed with distilled water to remove electrolytes released during leaf disc excision. Vials were then filled with $30 \mathrm{~mL}$ of distilled water and allowed to stand in the dark for $24 \mathrm{~h}$ at room temperature. Electrical conductivity (EC1) of the bathing solution was determined at the end of the incubation period. Vials were heated in a temperature-controlled water bath at $95^{\circ} \mathrm{C}$ for $20 \mathrm{~min}$ and then cooled to room temperature and the electrical conductivity (EC2) was again measured. Electrolyte leakage was calculated as a percentage of EC1/EC2 (Shi et al., 2006).

\section{Leaf Relative Water Content (LRWC)}

LRWC is a useful measure of the physiological water status of plants (Gonzalez \& Gonzalez-Vilar, 2001). Two leaves were collected among the young fully expanded leaves of two plants per replicate. Individual leaves detached from the stem were weighed to determine fresh weight (FW). In order to determine the turgid weight (TW), leaves kept floating in distilled water inside a closed petri dish. Leaf samples were weighed periodically, after gently wiping the water from the surface with the tissue paper until a steady weight was achieved. At the end of imbibition period, leaf samples were placed in a pre-heated oven at $70^{\circ} \mathrm{C}$ for $48 \mathrm{~h}$, in order to determine dry weight (DW). Values of FW, TW, and DW were used to calculate LRWC using the equation (Kaya et al., 2003): LRWC (\%) = $[(\mathrm{FW}-\mathrm{DW}) /(\mathrm{TW}-\mathrm{DW})] \times 100$

\section{Growth Parameters}

Sixty days after planting, eight plants from each replicate were harvested, and data on plant growth variables, such as shoot fresh weight, root fresh weight, shoot dry weight and root dry weight per plant were determined. The plant material for dry weight was dried at $70^{\circ} \mathrm{C}$ for 48 hours.

\section{Mineral Analysis}

In order to determine the mineral contents of shoot and root, samples were oven-dried at $70^{\circ} \mathrm{C}$ for $48 \mathrm{~h}$ and ground to pass $1 \mathrm{~mm}$. The Kjeldahl method (Bremner, 1996) and a Vapodest 10 Rapid Kjeldahl Distillation Unit (Gerhardt, Konigswinter, Germany) were used to determine total nitrogen. Phosphorus and sulphur contents were determined after wet digestion using a $\mathrm{HNO}_{3}-\mathrm{HClO}_{4}$ acid mixture (4:1 v/v) (AOAC922.02 2005). Phosphorus and sulphur in the extracted solution was measured spectrophotometrically using the indophenol-blue and ascorbic acid methods
(AOAC931.01 2005) and a UV/VIS Aqumat Spectrophotometer at $660 \mathrm{~nm}$ and at $440 \mathrm{~nm}$, respectively (Thermo Electron Spectroscopy LTD, Cambridge, UK). Potassium, sodium, calcium, magnesium, iron, manganese, zinc, and cupper were determined after wet digestion using a $\mathrm{HNO}_{3}-\mathrm{HClO}_{4}$ acid mixture (4:1 $\mathrm{v} / \mathrm{v})$. In the diluted digests, potassium, sodium, calcium, magnesium, iron, manganese, zinc, and cupper analysis were determined by atomic absorption spectrometry (Perkin Elmer 3690) (AOAC975.03 2005).

\section{Statistical Analysis}

The statistical analysis was made using the GLM procedure of SAS (SAS Institute, 1985). The experimental design was hierarchical with respect to two factors arranged in a completely randomized design with four replications. Data were subjected to analysis of variance (ANOVA) to compare the effects of salt stress treatments and SA treatments. The differences between the means were compared using the least significant difference test (LSD, $p<0.05$ ).

\section{RESULTS AND DISCUSSION}

Shoot fresh weight, shoot dry weight, root fresh weight and root dry weight of strawberry plants were lower at salt stress treatment as compared to nonsaline conditions $(p<0.05)$. Similar results have been shown by Kaya et al. (2002), Pirlak \& Esitken (2004) and Saied et al. (2005). However, exogenous SA applications increased these parameters as compared to the control under salt stress. The application of 1.00 $\mathrm{mM}$ SA under salt stress gave the higher values for these parameters than the other treatments except for root fresh weight. It increased by $82 \%$ the shoot fresh weight, by $62 \%$ the root fresh weight, by $37 \%$ the shoot and by $67 \%$ the root dry weight, as compared to the control. Furthermore, $1.00 \mathrm{mM} \mathrm{SA}$ application affected positively the growth of the strawberry plants compared to the other treatments (Figure 1). There was no interaction between salt stress and SA treatments in relation to growth parameters. Similar results were reported by El-Tayeb (2005) for barley, Stevens et al. (2006) and Szepesi et al. (2005) for tomato, Khodary (2004) and Gunes et al. (2007) for maize and Yildirim et al. (2008) for cucumber, who observed that exogenous SA treatments ameliorated the negative effects of salt stress on fresh and dry weights of plants. This positive effect of SA could be attributed to an increased $\mathrm{CO}_{2}$ assimilation and photosynthetic rate and increased mineral uptake by the stressed plant under SA treatment (Khan et al., 2003; Fariduddin et al., 2003; Szepsi et al., 2005).

Figure 2 shows the effect of salt stress and SA treatments on chlorophyll content, LRWC and elec- 

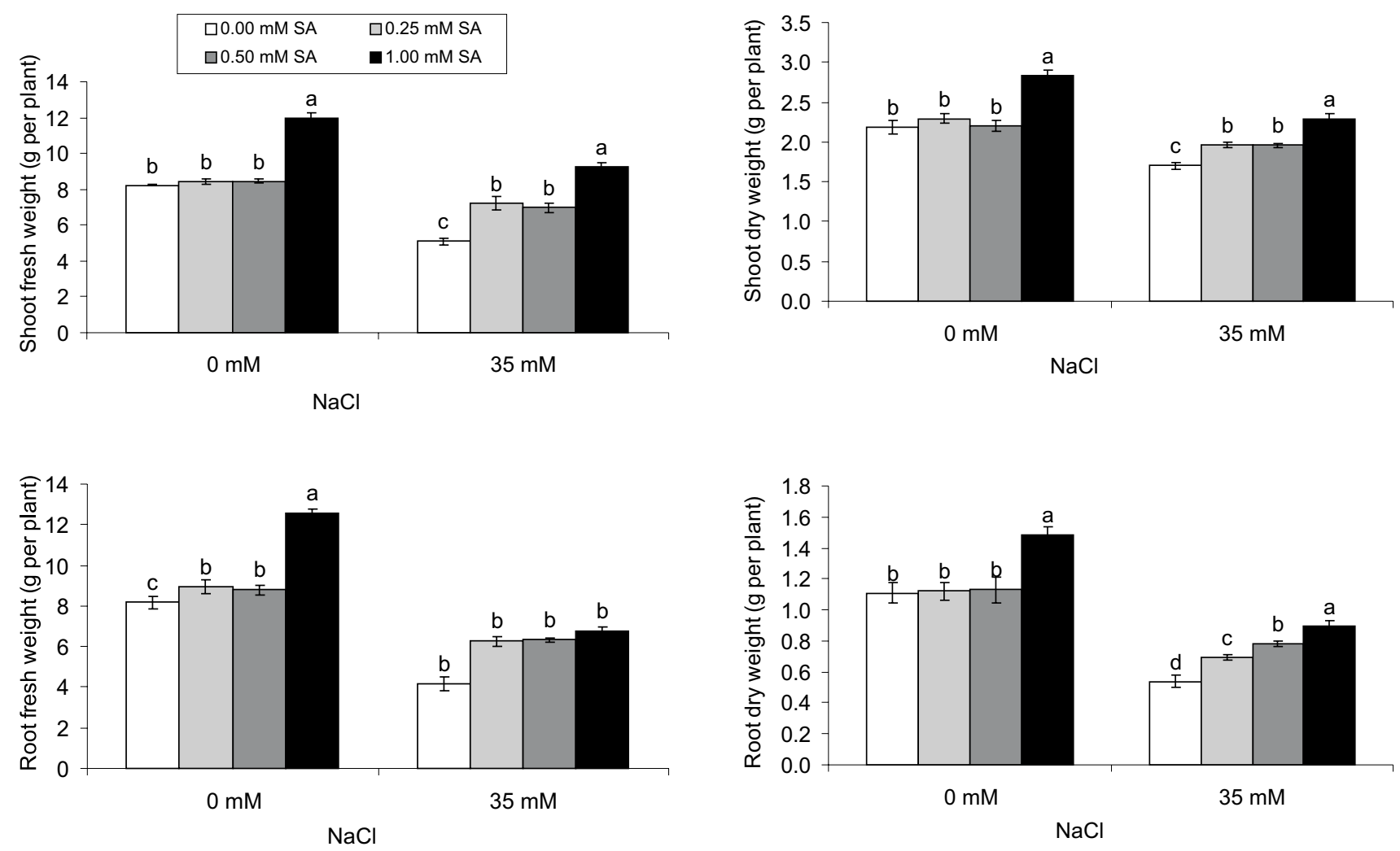

Figure 1 - Shoot fresh weight, shoot dry weight, root fresh weight and root dry weight of strawberry plants in response to SA applications under salt stress. Different letters on top of bars indicate differences (LSD test, $p<0.05$ at each salt level). Vertical bars indicate the mean $\pm \mathrm{SE}$.
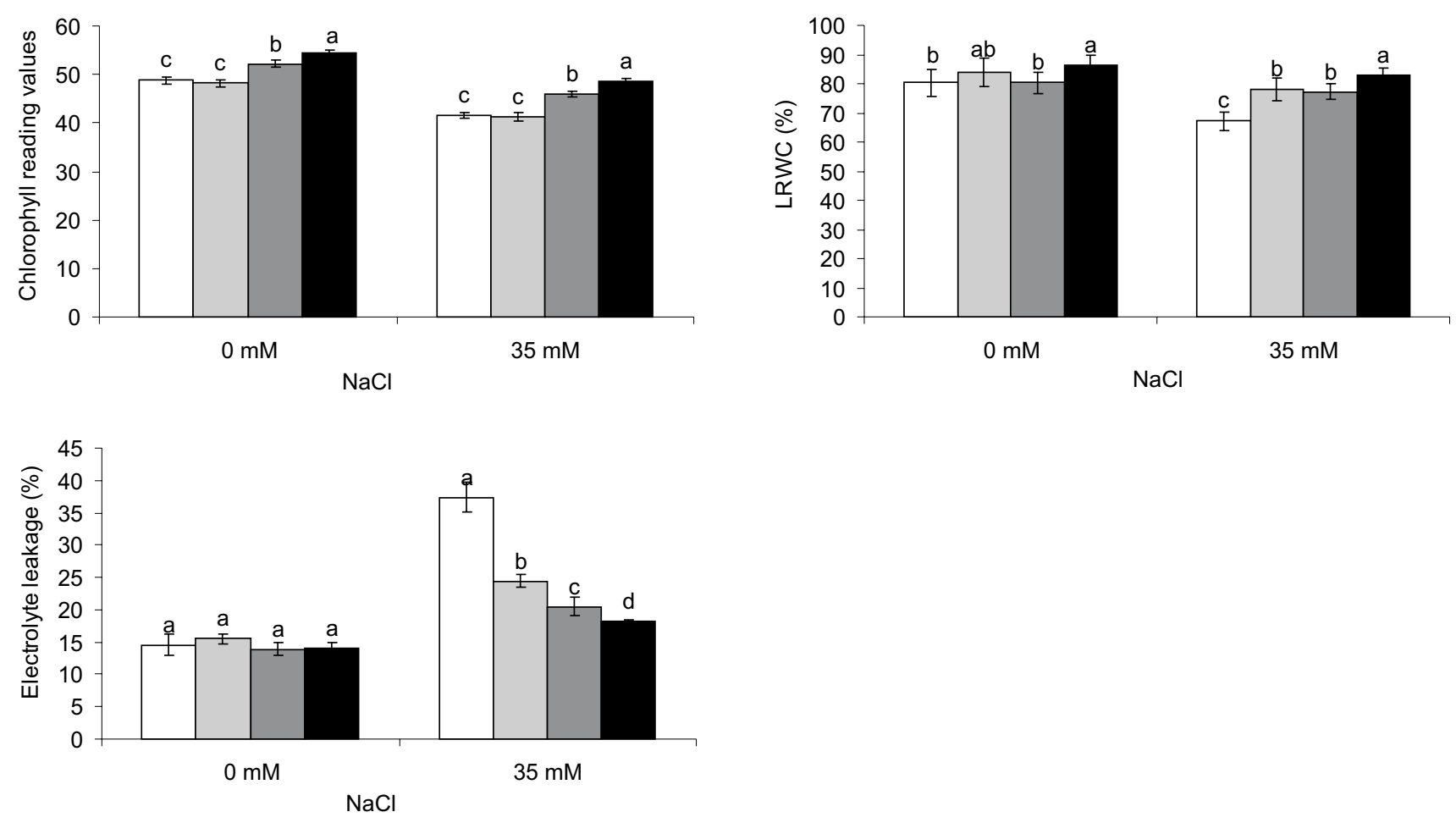

Figure 2 - Chlorophyll content, LRWC and electrolyte leakage of strawberry in response to SA applications under salt stress. Different letters on top of bars indicate differences (LSD test, $p<0.05$ at each salt level). Vertical bars indicate the mean $\pm \mathrm{SE}$. 
trolyte leakage of strawberry. Chlorophyll was affected by salinity and SA treatments $(p<0.05)$. Salt stress decreased chlorophyll reading as compared to the non-saline conditions. Similarly, the adverse effect of salt stress on chlorophyll content of strawberry has been shown by Kaya et al. (2002). Furthermore, salt stress inhibits the chlorophyll content in leaves of many crops (Parida \& Das, 2005). SA applications caused increased readings except for the $0.25 \mathrm{mM}$ SA treatment. The highest reading values were obtained from $1.00 \mathrm{mM} \mathrm{SA}$ application in both $\mathrm{NaCl}$ treatments (Figure 2). The increase in chlorophyll content with SA confirmed the reports of El-Tayeb (2005) for barley, Gunes et al. (2007) for maize and Yildirim et al. (2008) for cucumber. In this study, 0.50 and $1.00 \mathrm{mM}$ SA treatments caused an increase in the chlorophyll content of strawberry plants under salt stress absence (Figure 2). These results are in agreement with Moharekar et al. (2003) for wheat, Yildirim et al. (2006a) and Yildirim et al. (2008) for cucumber.

External $\mathrm{NaCl}$ salinity lowered LRWC of strawberry plants $(p<0.05)$ (Figure 2). Water stress often results when plants are subject to high salt concentrations (Gonzalez \& Gonzalez-Vilar, 2001). Parida \& Das (2005) reported that the relative water content, water potential and osmotic potential of plants become more negative with an increase in salinity. This study showed that SA treatments induced an increase in LRWC of the salt stressed plants as compared to the control plants (Figure 2). Increases in LRWC of strawberry plants treated with SA were also reported for other crops grown under salt stress including barley (El-Tayeb, 2005), tomato (Tari et al., 2002; Szepsi et al., 2005) and cucumber (Yildirim et al., 2008). This phenomenon may be attributed to the fact that foliar SA application can increase the leaf diffusive resistance and lower transpiration rates.

For the present experiment, a tendency towards elevated electrolyte leakage in leaves of salinised strawberry plants was detectable (Figure 2). Similar reports were presented by Parida \& Das (2005) and Yildirim et al. (2008) for several crops. High concentrations of $\mathrm{Na}$ caused membrane disorganization (Greenway \& Munns, 1980). Wu et al. (1998) pointed out that molar percentages of strerols and phospholipd decreased with increasing salinity. Electrolyte leakage enables cell membrane injury to be assessed when plants are subjected to salinity stress. Maintaining integrity of the cellular membranes under salt stress is considered an integral part of the salinity tolerance mechanism (Stevens et al., 2006). SA treatments lowered the electrolyte leakage in salt stressed strawberry plants (Figure 2). These results are concordant with
Stevens et al. (2006) for tomato and Yildirim et al. (2008) for cucumber, who determined that SA facilitated the maintenance membrane functions. This facilitation could be attributed to the induction of antioxidant responses and elevated $\mathrm{Ca}$ uptake that protects the plant from the oxidative damage by SA (Seneratna et al., 2000; El-Tayeb, 2005).

$\mathrm{N}, \mathrm{P}, \mathrm{K}, \mathrm{Ca}, \mathrm{Mg}$ and the other minerals in both shoot and roots of strawberry plants decreased dramatically with the increasing $\mathrm{NaCl}$ concentration $(p<0.05)$ (Figures 3 and 4). Salinity dominated by $\mathrm{Na}$ and $\mathrm{Cl}$ ions has been shown to decrease the concentration of essential macro and micro elements in several vegetable crops (Martinez \& Cerda, 1989; Feigin et al., 1987; Feigin et al., 1991; Grattan \& Grieve, 1999; Gadallah, 1999; Yildirim et al., 2006b). Salt stress increased the $\mathrm{Na}$ content in both organs of strawberry plants (Figures 3 and 4). Sivritepe et al. (2003) and De- Pascale et al. (2003) found that $\mathrm{NaCl}$ salinity increased $\mathrm{Na}$ content in plant tissue of some crops. Essa (2002) reported that $\mathrm{NaCl}$ salinity may produce extreme ratios of $\mathrm{Na} / \mathrm{Ca}$ and $\mathrm{Na} / \mathrm{K}$ in the plants, causing them to be susceptible to osmotic and specific-ion injury, as well as to nutritional disorders.

SA reduced the Na uptake of plants and/or increased the uptake of $\mathrm{N}, \mathrm{P}, \mathrm{K}, \mathrm{Ca}, \mathrm{Mg}$ and the other minerals as compared to control treatment under salt stress (Figures 3 and 4). These results are consistent with those of El-Tayeb (2005) for barley, Gunes et al. (2005) and Gunes et al. (2007) for maize, (Szepsi et al., 2005) for tomato and Yildirim et al. (2008) for cucumber, who found out that exogenous SA applications inhibited $\mathrm{Na}$ accumulation, but stimulated $\mathrm{N}, \mathrm{P}$, $\mathrm{K}, \mathrm{Mg}, \mathrm{Fe}, \mathrm{Mn}$ and $\mathrm{Cu}$ uptake. An increase in concentration of $\mathrm{K}$ and $\mathrm{Ca}$ in plants under salt stress could ameliorate the deleterious effects of salinity on growth and yield (Grattan \& Grieve, 1999). Alteration of mineral uptake from SA applications may be one mechanism for the alleviation of salt stress.

In conclusion, exogenous SA treatments did not completely recover the deleterious effects of salt stress on the growth of strawberry plants, but especially the $1.00 \mathrm{mM} \mathrm{SA}$ concentration improved plant tolerance to salinity as compared to the non-treated plants. Based on these findings, the SA treatments may ameliorate the negative effect of salinity on the growth of strawberry.

The addition of SA could offer an economical and simple application to the salt sensitive plant of strawberry production problems in aridisol caused by high salinity but further studies are required in order to determine the efficiency of these materials under natural field condition 

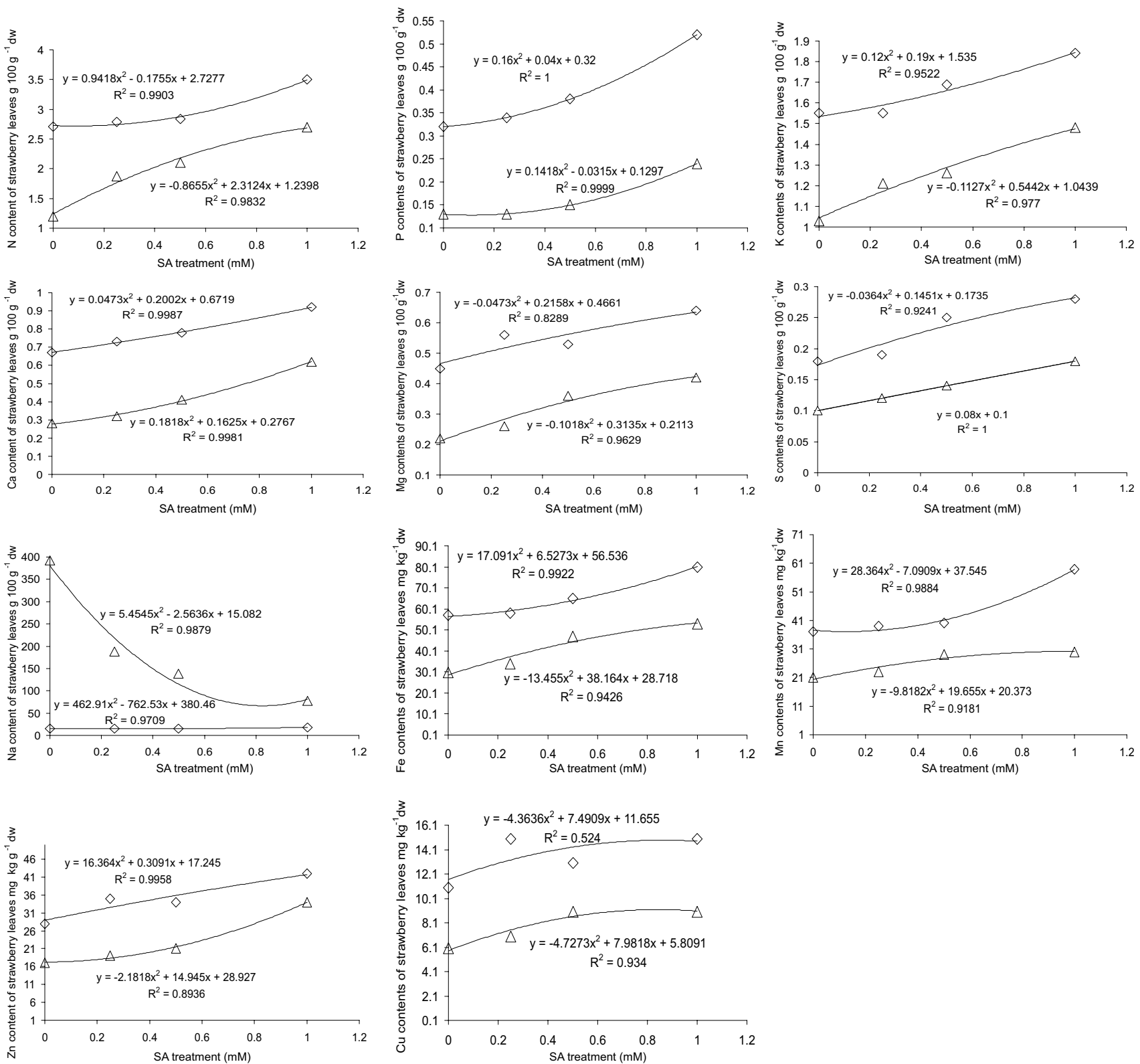

Figure 3 - Effect of exogenous SA treatments on mineral content in leaves of strawberry under salt stress ( $\diamond$ without saline solution; $\triangle 35 \mathrm{mM}$ saline solution).

\section{ACKNOWLEDGEMENTS}

To the Atatürk University for financial support; to Dr. Fahrettin GOKTEPE, from The Colorado State University for his critical reading of the manuscript.

\section{REFERENCES}

ALDESUQUY, H.S.; MANKARIOS, A.T.; AWAD, H.A. Effect of some antitranspirants on growth, metabolism and productivity of saline-treated wheat plants. Induction of stomatal closure, inhibition of transpiration and improvement of leaf turgidity. Acta Botanica Hungarica, v.41, p.1-10, 1998.

ASSOCIATION OF OFFICIAL ANALYTICAL CHEMISTSINTERNATIONAL - AOAC. Official methods of analysis. 18 ed. Gaithersburg: AOAC, 2005. p.2087-2417.
BREMNER, J.M. Nitrogen total. In: SPARKS, D.L. (Ed.) Methods of soil analysis. Part III. Chemical methods. 2 ed. Madison: America Society of Agronomy, 1996. p.10851122 .

BREUSEGEM, F.V.; VRANOVA, E.; DAT, J.F.; INZE, D. The role of active oxygen species in plant signal transduction. Plant Science, v.161, p.405-414, 2001.

DE-PASCALE, S.D.; RUGGIERO, C.; BARBIERI, G.; MAGGIO, A. Physiological responses of pepper to salinity and drought. Journal of the American Society Horticultural Science, v.128, p.48-54, 2003.

EL-TAYEB, M.A. Response of barley grains to the interactive effect of salinity and salicylic acid. Plant Growth Regulation, v.45, p.215-224, 2005.

ESSA, T.A. Effect of salinity stress on growth and nutrient composition of three soybean (Glycine max L. Merrill) cultivars. Journal of Agronomy and Crop Science, v.188, p.86-93, 2002 . 
3.
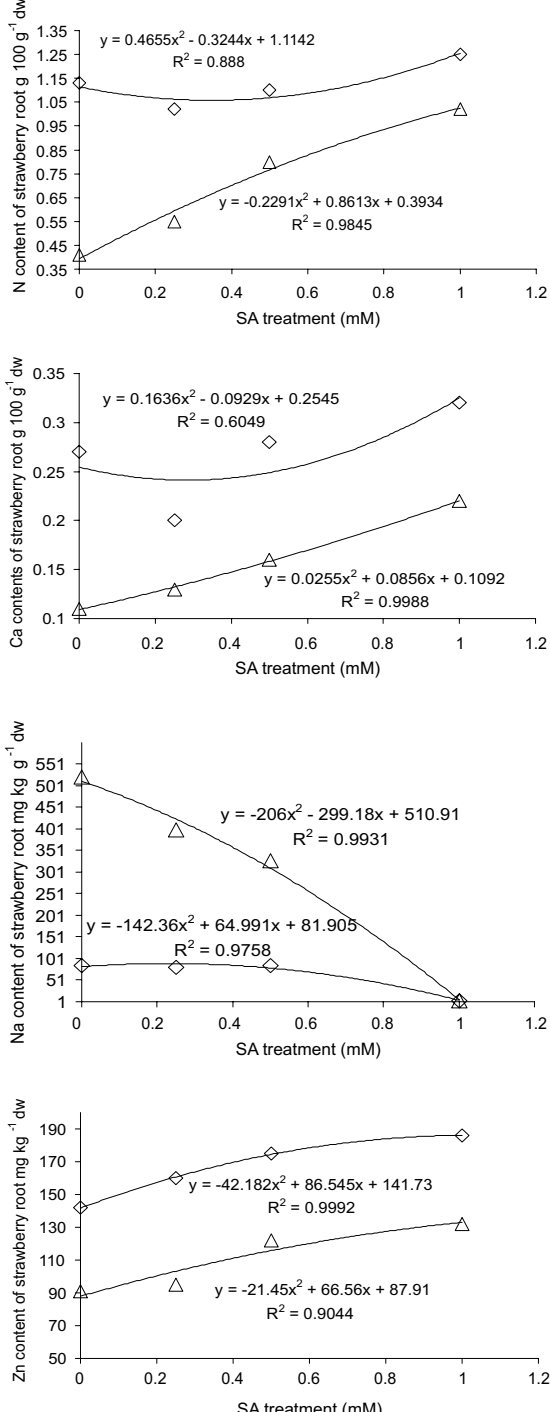
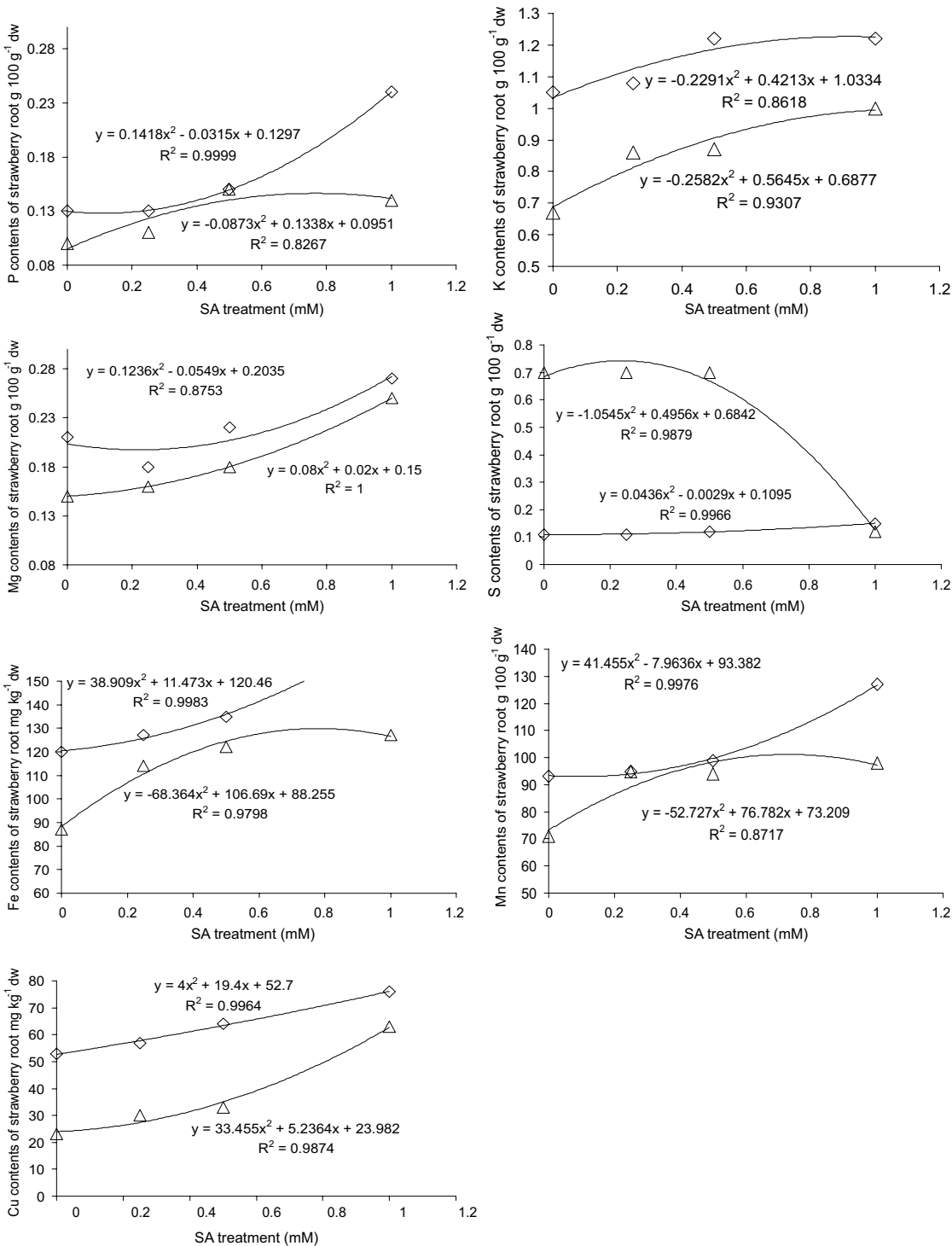

Figure 4 - Effect of exogenous SA treatments on mineral content in roots of strawberry under salt stress ( $\diamond$ without saline solution; $\triangle 35 \mathrm{mM}$ saline solution).

FARIDUDDIN, Q.; HAYAT, S.; AHMAD, A. Salicylic acid influences net photosynthetic rate, carboxylation efficiency, nitrate reductase activity, and seed yield in Brassica juncea. Photosynthetica, v. 41, p.281-284, 2003.

FEIGIN, A.; PRESSMAN, E.; IMAS, P.; MILTAU, O. Combined effects of $\mathrm{KNO}_{3}$ and salinity on yield and chemical composition of lettuce and chinese cabbage. Irrigation Science, v.12, p.223230, 1991 .

FEIGIN, A.; RYLSKI, I.; MEIRI, A.; SHALHEVET, J. Response of melon and tomato plants to chloride-nitrate ratios in saline nutrient solutions. Journal of Plant Nutrition, v.10, p.17871794, 1987.

GADALLAH, M.A.A. Effects of proline and glycinebetaine on Vicia faba response to salt stress. Biologia Plantrum, v.42, p.249-257, 1999.

GONZALEZ, L.; GONZALEZ-VILAR, M. Determination of relative water content. In: REIGOSA, M.J. Handbook of plant ecophysiology techniques. Dordrecht: Kluwer Academic, 2001. p.207-212.

GRATTAN, S.R.; GRIEVE, C.M. Salinity-mineral nutrient relations in horticultural crops. Scientia Horticulturae, v.78, p.127157,1999
GREENWAY, H.; MUNNS, R. Mechanisms of salt tolerance in nonhalophytes. Annual Review of Plant Physiology, v.31, p.149-190, 1980.

GUNES, A.; INAL, A.; ALPASLAN, M.; CICEK, N.; GUNERI, E.; ERASLAN, F.; GUZELORDU, T. Effects of exogenously applied salicylic acid on the induction of multiple stress tolerance and mineral nutrition in maize (Zea mays L.). Archives of Agronomy and Soil Science, v.51, p.687-695, 2005.

GUNES, A.; INAL, A.; ALPASLAN, M.; ERASLAN, F.; BAGCI, E.G.; CICEK, N. Salicylic acid induced changes on some physiological parameters symptomatic for oxidative stress and mineral nutrition in maize (Zea mays L.) grown under salinity. Journal of Plant Physiology, v.164, p.728-736, 2007.

KAYA, C.; HIGGS, D.; INCE, F.; AMADOR, B.M.; CAKIR, A.; SAKAR, E. Ameliorative effects of potassium phosphate on salt-stressed pepper and cucumber. Journal of Plant Nutrition, v.26, p.807-820, 2003.

KAYA, C.; KIRNAK, H.; HIGGS, D.; SALTATI, K. Supplementary calcium enhances plant growth and fruit yield in strawberry cultivars grown at high $(\mathrm{NaCl})$ salinity. Scientia Horticulturae, v.26, p.807-820, 2002. 
KHAN, W.; PRITHIVIRAJ, B.; SMITH, D.L. Photosynthetic responses of corn and soybean to foliar application of salicylates. Journal of Plant Physiology, v.160, p. 485-492, 2003.

KHODARY, S.E.A. Effect of salicylic acid on the growth, photosynthesis and carbohydrate metabolism in salt-stressed maize plants. Journal of Agricultural Biology, v.6, p.5-8, 2004.

MARTINEZ, V.; CERDA, A. Influence of $\mathrm{N}$ source on rate of $\mathrm{Cl}$, $\mathrm{N}, \mathrm{Na}$, and $\mathrm{K}$ uptake by cucumber seedlings grown in saline conditions. Journal of Plant Nutrition, v.12, p.971-983, 1989.

MOHAREKAR, S.T.; LOKHANDE, S.D.; HARA, T.; TANAKA, R.; TANAKA, A.; CHAVAN, P.D. Effect of salicylic acid on chlorophyll and carotenoid contents of wheat and moong seedlings. Photosynthetica, v.41, p.315-317, 2003.

MURILLO-AMADOR, B.; JONES, H.G.; KAYA, C.; AGUILAR, R.L.; GARCIA-HERNANDEZ, J.L.; TROYO-DIEGUEZ, E.; AVILA-SERRANO, N.Y.; RUEDA-PUENTE, E. Effects of foliar application of calcium nitrate on growth and physiological attributes of cowpea (Vigna unguiculata L. Walp.) grown under salt stress. Environmental and Experimental Botany, v.58, p.188-196, 2006.

NEUFELD, H.; CHAPPELKA, A.H.; SOMERS, G.L.; BURKEY, K.O.; DAVISON, A.W.; FINKELSTEIN, P. Visible foliar injury caused by ozone alters the relationship between SPAD meter readings and chlorophyll concentrations in cut leaf coneflower. Photosynthetic Research, v.87, p.281-286, 2006.

PARIDA, A.K.; DAS, A.B. Salt tolerance and salinity effects on plants: a review. Ecotoxicology and Environmental Safety, v.60, p.324-349, 2005.

PEREZ, A.G.; OLIAS, R.; ESPADA, J.; OLIAS, J.M.; SANZ, C. Rapid determination of sugars, nonvolatile acids, and ascorbic acid in strawberry and fruits. Journal of Agriculture and Food Chemistry, v.45, p.3545-3549, 1997.

PIRLAK, L.; ESITKEN, A. Salinity effects on growth, proline and ion accumulation in strawberry plants. Acta Agriculturae Scandinavica. Section B - Plant Soil Science, v.54, p.189-192, 2004.

QADÝR, M.; GHAFOOR, A.; MURTAZA, G. Amelioration strategies for saline soils: a review. Land Degradation Dev, v.11, p.501$521,2000$.

SAIED, A.S.; KEUTGEN, A.J.; NOGA, G. The influence of $\mathrm{NaCl}$ salinity on growth, yield and fruit quality of strawberry cvs. 'Elsanta' and 'Korona'. Scientia Horticulturae, v.103, p.289-303, 2005.

SAS INSTITUTE. SAS introductory guide. 3 ed. Carey: SAS Institute, 1985. 99p.

SENARATNA, T.; TOUCHELL, D.; BUNN, E.; DIXON, K. Acetyl salicylic acid (Aspirin) and salicylic acid induce multiple stress tolerance in bean and tomato plants. Plant Growth Regulation, v.30, p.157-161, 2000.
SHI, Q.; BAO, Z.; ZHU, Z.; YING, Q.; QIAN, Q. Effects of different treatments of salicylic acid on heat tolerance, chlorophyll fluorescence, and antioxidant enzyme activity in seedlings of Cucumis sativa L. Plant Growth Regulation, v.48, p.127135,2006

SIVRITEPE, N.; SIVRITEPE, H.O.; ERIS, A. The effects of $\mathrm{NaCl}$ priming on salt tolerance in melon seedlings grown under saline conditions. Scientia Horticulturae, v.97, p.229-237, 2003.

STEVENS, J.; SENARATNA, T.; SIVASITHAMPARAM, K. Salicylic acid induces salinity tolerance in tomato (Lycopersicon esculentum cv. Roma): associated changes in gas exchange, water relations and membrane stabilisation. Plant Growth Regulation, v.49, p.77-83, 2006.

SZEPESI, A.; CSISZAR, J.; BAJKAN, S.; GEMES, K.; HORVATH, F.; ERDEI, L.; DEER, A.K.; SIMON, M.L.; TARI, I. Role of salicylic acid pre-treatment on the acclimation of tomato plants to salt- and osmotic stress. Acta Biologica Szegediensis, v.49, p.123-125, 2005.

TARI, I.; CSISZAR, J.; GABRIELLA, S.; HORVATH, F.; PECSVARADI, A.; KISS, G.; SZEPSI, A.; SZABO, M.; ERDEI, L. Acclimation of tomato plants to salinity stress after a salicylic acid pre-treatment. Acta Biologica Szegediensis, v.46, p.5556,2002

WANG, S.Y.; GALLETTA, G.J. Compositional change in Colletotrichum (Anthracnose) infected strawberry fruit. Acta Horticulture, v.567, p.815-819, 2002.

WU, J.L.; SELISKAR, D.M.; GALLAGHER, J.L. Stress tolerance in the marsh plane Spartina patens: impact of $\mathrm{NaCl}$ on growth and root plasma membrane lipid composition. Physiology Plantrum, v.102, p.307-317, 1998.

YILDIRIM, E.; GUVENC, I.; KARATAS, A. Effect of different number foliar salicylic acid applications on plant growth and yield of cucumber. In: TURKEY NATIONAL VEGETABLE SYMPOSIUM, 6., Kahramanmaras, 2006. Abstracts. Kahramanmaras: KSU/Faculty of Agriculture, 2006a p.9094.

YILDIRIM, E.; TAYLOR, A.G.; SPITTLER, T. D. Ameliorative effects of biological treatments on growth of squash plants under salt stress. Scientia Horticulturae, v.111, p.1-6, 2006b.

YILDIRIM, E.; TURAN, M.; GUVENC, I. Effect of foliar salicylic acid applications on growth, chlorophyll and mineral content of cucumber (Cucumis sativus L.) grown under salt stress. Journal of Plant Nutrition, v.31, p.593-612, 2008.

Received May 25, 2007

Accepted March 13, 2008 